\title{
Semarang City's Resilient Strategy Facing Covid-19
}

\author{
Adi Ekopriyono \\ Faculty of Economics and Business, University of 17 August 1945 Semarang \\ adieko.bsf@gmail.com
}

Received: 14/01/2021.

Reviewed: invited author.

Published: 28/04/2021

Copyright $\odot 2021$ by the author (et al) and Jurnal

Sosial Humaniora (JSH)

*This work is licensed under the Creative Commons Attribution International License (CC BY 4.0) http://creativecommons.org/licenses/by/4.0/

\begin{abstract}
Subject Area: Sociology
Abstract

Semarang City is the first city in Indonesia to be selected in the 100 Resilient Cities (100 RC) Program. This position raises the hope that this city has more potential than other cities to prevent and control the spread of Covid-19. The policies pursued through Restrictions on Community Activities and the Candi Hebat Siaga Village Program have not yet been optimal in breaking the chain of Covid-19 spread. This study uses a descriptive qualitative approach, examines the factors that influence, and formulates the steps that need to be taken to increase its effectiveness. The most prominent factor found in this study is the weak resilience of local culture concerning the prevention and control of Covid-19. This weakness causes the community to be less disciplined in implementing health protocols and the apparatus less control over the implementation of policies.
\end{abstract}

Keywords: 100 RC; Restrictions; Kampung Siaga Candi Hebat; cultural resilience.

\section{Introduction}

The development of cities around the world is very significant. By 2050, it is predicted that $75 \%$ of the world's population will live in cities. Economic factors are the main cause of this phenomenon, supported by infrastructure, technology, and educational facilities, making cities a strong magnet to attract the population. Cities must have a way or strategy to survive and adapt to problems that arise. City Resilience is the capacity of individuals, communities, institutions, companies, and systems within the city to survive, adapt and grow in the presence of various shocks and pressures experienced, both physically and socially. In addition to positively impacting people's welfare, rapid economic and population growth also has multiple risks that must be faced and adapted (Pemerintah Kota Semarang, 2016).

Half of humanity is now living in cities, according to the United Nations Population Division. The urban population exceeded the rural for the first time in 2008 , and by 2050 urbanization will rise to 70 percent with increased urban risk. Today, 100 cities are in control of 30 percent of the world's economy.' The need for maintenance and upkeep of these cities makes safety measures for their citizens crucial. In this context, urban risk, city planning, and the role of local governments in dealing with risk reduction have been recognized as key factors to build communities resilient to disasters. While many local governments have 
taken action to reduce vulnerability, especially when it comes to government organizing capacity to deal with disasters, much remains to be done (Paola, 2012).

Semarang City is the first city in Indonesia to be selected in the 100 Resilient Cities (100 RC) Program, along with New York City (USA), Medellín (Colombia), Porto Alegre (Brazil), Quito (Ecuador), Rio De Janeiro (Brazil), Surat (India), Bangkok (Thailand), Mandalay (Philippines), Da Nang (Vietnam), Glasgow (England), Rome (Italy), Rotterdam (Netherlands), Dakar (Senegal), and Durban (South Africa) and others. Funded by the Rockefeller Foundation, the program aims to help cities be resilient in facing physical, social, economic challenges and develop and implement urban resilience strategies.

The City Resilience Strategy is an integrated approach to building resilience against various shocks and stresses. Resilience strategies can minimize costs from shocks and stresses and can increase community participation. This strategy is then expected to be integrated with city programs to be realized and sustainable. The six pillars within the $100 \mathrm{RC}$ framework are sustainable water and energy, new economic opportunities, preparedness for the risk of disasters and disease outbreaks, integrated mobility, transparent public information and governance, and competitive human resources (Pemerintah Kota Semarang, 2016).

Regarding the risk of disasters and disease outbreaks, Semarang City is vulnerable to the risk of floods, landslides, and dengue fever outbreaks. The public needs to know about this risk so that they are better prepared to face it. Information about disaster risks and disease outbreaks must be disseminated to the public. Various issues of disasters and disease outbreaks pose particular challenge that need to be anticipated. Semarang must be ready to face this challenge to reduce its impact. Steps that need to be taken include increasing information dissemination, innovation, and collaboration in preparation for disasters and disease outbreaks.

In the context of these six pillars, preparedness to face the spread of the Covid-19 pandemic is very relevant to be studied. Two Semarang City Government policies are relevant to preventing the spread of the pandemic, namely Restrictions on Community Activities (Pembatasan Kegiatan Masyarakat - PKM) and Kampung Siaga Candi Hebat (Candi Hebat Alert Village). Ideally, the two policies are a continuation or implementation of the $100 \mathrm{RC}$ concept, especially the pillars of risk for disease outbreaks. The Semarang City Government has also created a page labeled "Semarang City Corona Alert" https://siagacorona.semarangkota.go.id/. This page contains, among other things, Covid-19 data, information on social assistance, the task force, spraying schedules, availability of medical devices, patient referrals, assistance data, monitoring of basic materials.

The implementation of PKM is contained in Semarang Mayor Regulation Number 28 of 2020 concerning the Implementation of Restrictions on Community Activities in the Context of Accelerating Handling of Covid-19 in the City of Semarang (Peraturan Wali Kota Semarang Nomor 28 Tahun 2020, 2020). Article 19 states that the public can participate in the form of (a) make donations in the form of suggestions, thoughts, money, goods, and activities to prevent the spread of Covid-19; (b) remind each other among community members to apply health protocols, and (c) make efforts to safeguard the roads in their respective neighborhoods. Article 19 also states that to participate in dealing with the social and economic impacts of the Covid-19 pandemic, the public can participate in the form of procuring food barns in the 
neighborhoods of Neighborhood Association (Rukun Tetangga - RT), Citizens Association (Rukun Warga RW), kelurahan (sub-district).

In connection with community participation, the Kampung Siaga Candi Hebat Program was implemented. This program was started in April 2020 and was initiated by the Semarang Big City Police Resort (Polrestabes) and Military Regional Command (Kodim) to break the chain of the Covid-19 spread while increasing residents' social-economic resilience based on the concept of self-help and cooperation. With awareness and friendship, residents made several efforts to prevent the spread of Covid-19, starting from checking body temperature, providing isolation rooms, distributing groceries, foodstuffs, and vitamins for residents. Every day, residents are given food with a nutritional value expected to increase immunity, such as milk, green beans, ginger, fruit, vegetables, and side dishes. Residents are also economically independent by developing several business activities.

The city government provides support by assisting in stimuli according to the community's needs, such as plant and fish seeds and various Covid-19 prevention needs such as hand sanitizers and disinfectants. It is hoped that the program will foster physical endurance and economic activity in the community. Besides, residents can protect themselves through socialization, tightening health protocols, providing independent isolation places, residents' barns, and food security. Although Semarang City has been selected in $100 \mathrm{RC}$, implemented PKM, and the Kampung Siaga Candi Hebat Program, the data shows that the number of Covid19 cases in the capital city of Central Java Province is high. In the Covid-19 virus update in Semarang City on January 8, 2021, from the page, https://siagacorona.semarangkota.go.id/ confirmed cases reached 22,286, with details of 952 cases still undergoing treatment, 679 from within Semarang City and 273 from outside the city of Semarang. These figures show that the policies implemented have not optimally yet prevented the spread of Covid-19. Therefore, it is interesting to study the factors that influence the effectiveness of the policies adopted and the strategies to increase the efficacy.

The Covid-19 pandemic has also had an impact on revenue in the Semarang City 2020 Budget Year (Anggaran Pendapatan dan Belanja Daerah - APBD). Original Regional Revenue (Pendapatan Asli Daerah PAD) decreased by IDR 390 billion (39 percent of the target of the 2020 Fiscal Year Main APBD). Balanced Funds (Special Allocation Fund or Dana Alokasi Khusus - DAK, General Allocation Fund or Dana Alokasi Umum - DAU, Profit Sharing) decreased by IDR 184 billion (10 percent), Other Regional Revenues which have decreased by IDR 90 billion (11.5 percent). Total Regional Income decreased by IDR 1.23 trillion (24 percent).

Some previous literature has discussed urban resilience, including research conducted by Johnson \& Blackburn (2014), which states, definitions of resilience include an emphasis on adaptive capacity, which is, for instance, seen as a vital determinant of a resilient city and an essential response to climate change. Adaptive capacity is defined as "... the ability to plan, prepare for, facilitate and implement adaptation options", and determinants include wealth, technology, infrastructure, information, knowledge and skills, commitment to equity, and social capital. This definition reflects the fact that not all communities, sectors, and households have equal access. 
Citizens are the primary actors or agents in networks and thus largely shape a city's patterns, including social, economic, environmental, and increasingly governance network dynamics. Citizens can share information through social and mobile networks that alert their peers within the same city and beyond about activities, their safety during an emergency, and political views among other purposes (Desouza \& Flanery, 2013).

Socio-environmental resilience can be conceived and practiced at a variety of scales and configurations - ranging outward from individuals to households, communities, neighborhoods, firms, civil society institutions, governance structures, and infrastructure networks, as well as to supra-urban forces of subnational regional hinterlands and even multinational regions. Consequently, the significance of resilience depends on whose resilience is being described. One must ask: Resilience for whom and against what? Many different entities (e.g., individuals, communities, academic disciplines, professional fields, governments, corporations) all seek to claim the term. How do they decide whose resilience to care about? And whose resilience is omitted in the process? (Vale, 2014).

The environmental concept of protection and conservation subtly begins to "oscillate" when more process-related ideas like harvesting and growth are infused; such accompanied by social and economic aspects, the concept of sustainability ascends as the new star in the age of growth. Similarly, and shortly after, the concept of climate change mitigation (not implying much dynamic from its literal interpretation) seems to give in and acknowledges the phenomenon of change followed by the necessity of changing our behavior; and with this more flexible as well as pro-active twist climate change adaptation soon complements the picture of the urban development discourse (Stumpp, 2013).

Resilience is not just about the economy and environment but also society and culture. It does not merely refer to readiness to the surprise or isolated occurrences but also refers to long-term strategies to mitigate and adapt to socio-economic as well as environmental challenges. In a world of limited resources, resilience thinking can help integrate the issues of social, economic, and environmental well-being by strategically navigating the policy and planning to proactively create, assume and shape change (Mehmood, 2016). The literature examines the resilience of cities but is not related to the conditions of the Covid-19 pandemic. Therefore, this article seeks to provide a specific description of the city's resilience during the pandemic, more specifically regarding the Semarang City resilient strategy to face Covid-19.

\section{Literature Review}

Several previous studies have examined City Resilience, Limitation of Community Activities, and the Alert Village Program. Research by Rukuh Setiadi and Fitri Wulandari (Setiadi \& Wulandari, 2016), for example, specifically introduced an analytical framework to encourage the integration of urban resilience strategies. The case story in Semarang City shows that the cross-focus area stage in $100 \mathrm{RC}$ challenges city actors to think harder in producing a sharper and more integrated strategy.

Other research related to City Resilience conducted by Shafira et al., (2020) suggests that a comprehensive evaluation of the application of categories and objectives of resilient cities is needed in the policy document for resilience strategy for 100 Resilient Cities. Apart from that, it is also necessary to 
improve the quality of applying the categories and objectives of resilient cities in the policy document for resilience strategies owned by cities with the status of 100 Resilient Cities. The two studies analyzed general urban resilience on six pillars. The study conducted by the author focuses on the pillars of preventing disease outbreaks, even more specifically in the Covid-19 pandemic.

Meanwhile, Ni Nyoman Pujaningsih, I.G.A.AG Dewi Sucitawathi P (Pujaningsih \& Sucitawathi, 2020) conducted research on Limiting Community Activities conducted, who concluded that the implementation of PKM policies in overcoming the Covid 19 outbreak in Denpasar City had been effective. Supervision is carried out starting from masks, the community's prohibition without a clear purpose, supervision of full passenger vehicles, and goods vehicle activities. Also, monitoring community crowds, eating places, restaurants, restaurants, cafes, food stalls, depots, street vendors in food and beverage businesses, and malls that are only allowed to open until 21:00. The involvement of the traditional village is very helpful for government programs in overcoming Covid-19 because the village management, through the Banjar committee, better understands the community's situation and conditions in their environment. The involvement of other agencies such as the military and police is very helpful for creating security and order during PKM activities.

Another study conducted by Putu Lantika Oka Permadhi and I Made Sudirga (Permadhi \& Sudirga, 2020) concluded that policies that limit community activities are not easy to implement. Especially for people whose livelihoods are in the informal sector. People whose livelihoods are in the informal sector feel confused about how to meet their daily needs, so a good solution is needed to prevent Covid-19 transmission but not burden the community's economy. The government, in this case, the Denpasar City government, needs to conduct a further evaluation to find out people's behavior after the implementation of this PKM to break the chain of the Covid-19 pandemic.

The object of the two studies on PKM is the people of Denpasar City, who are known to still adhere to adat strongly. Of course, this is different from the characteristics of Semarang City people, who are more heterogeneous and less strong in their typical application than the people of Denpasar. Therefore, research on the application of PKM in Semarang City will be different. There has been no specific research regarding the Kampung Siaga Program. The study conducted by Sandy Isna Maharani et al. (Maharani et al., 2018) examined Community Empowerment through Desa Siaga in Bergas Semarang Regency. The study concluded that the Village Forum specifically discussing alert villages had never been carried out. Still, deliberations related to health problems were held simultaneously with regular community meetings at the RT, RW, and village levels. Obstacles to implementing an alert village include Coordination with the community, Funding, implementing personnel, the military, and police is very helpful for creating security and order during PKM activities, assistance from the local government regarding suggestions, funds to support the standby village.

Another study conducted by Liana Detania Rahantoknam, who analyzed Desa Siaga in Evu Village, Southeast Maluku Regency (Rahantoknam, 2013), concluded that the community could find and know their problems village. Therefore, deliberation was held based on the reflective survey results, the monitoring for the technical team improving guidance. The development of Alert Village in Evu Village, Southeast Maluku 
Regency, has been going well but needs to be improved. The main steps that need to be taken are developing a team of officers, team development in the community, self-awareness surveys, village community deliberations, village health posts, and cross-sector guidance and improvement.

The two research objects are villages in the regency area. In contrast, the object of the study conducted by the author is an urban village. In this case, the city of Semarang, which has different characteristics from the village's characteristics. This study is expected to provide an overview of the Kampung Siaga Program's implementation, which has not been researched by other researchers.

\section{Research Problems}

Based on the introduction's description, the core problem of this research is what factors influence and not yet being optimally effective in the Candi Hebat Siaga Village program in preventing and controlling Covid-19, that describing in the following research questions:

1) How is the implementation of the City Resilience concept with the policy of Restricting Community Activities and the Kampung Siaga Candi Hebat?

2) Why has the Kampung Siaga Candi Hebat not been optimally successful in suppressing the spread of Covid-19?

3) What factors influence the success of Covid-19 prevention in the framework of City Resilience, Restrictions on Community Activities, and Kampung Siaga Candi Hebat?

4) How to increase the effectiveness of policies in preventing and controlling Covid-19?

\section{Research Purposes}

Based on the research problem, the objectives of this study are:

1) Describe the City Resilience Program's implementation with the Policy on Restricting Community Activities and the Kampung Siaga Candi Hebat.

2) Describe the causes of the Kampung Siaga Candi Hebat that have not optimally succeeded in suppressing the spread of Covid-19.

3) Describe the factors that affect the success of preventing Covid-19 in the framework of City Resilience, Restrictions on Community Activities, and the Kampung Siaga Candi Hebat.

4) Describe the model for increasing the effectiveness of policies in preventing and controlling Covid-

19 through the City Resilience Program, Restricting Community Activities, and Kampung Siaga Candi Hebat.

\section{Methodology}

This study uses a qualitative approach with descriptive methods. The researcher acts as a participant, taking advantage of the position as a member of the 100 RC Program Supervisory Committee and Secretary II of the Semarang City Development Advisory Council (Dewan Pertimbangan Pembangunan Kota DP2K). Thus, the authors are freer to explore information relevant to the problem and research objectives, 
either through observation, interviews, or discussion forums regarding City Resilience, Restrictions on Community Activities, and the Kampung Siaga Candi Hebat.

\section{Data Collection}

This study's data were obtained from the writer's notes while the author being a member of the $100 \mathrm{RC}$ Program Supervisory Committee and Secretary II of the Semarang City Development Advisory Council (DP2K). Primary data were obtained from interviews and discussions with the Regional Implementing Organization (Organisasi Perangkat Daerah - OPD) leaders, which handled the 100 RC Program, Restrictions on Community Activities, and the Kampung Siaga Candi Hebat. Secondary data were obtained from documents related to the 100 RC Program, Restrictions on Community Activities, and the Kampung Siaga Candi Hebat.

\section{Conceptual Model}

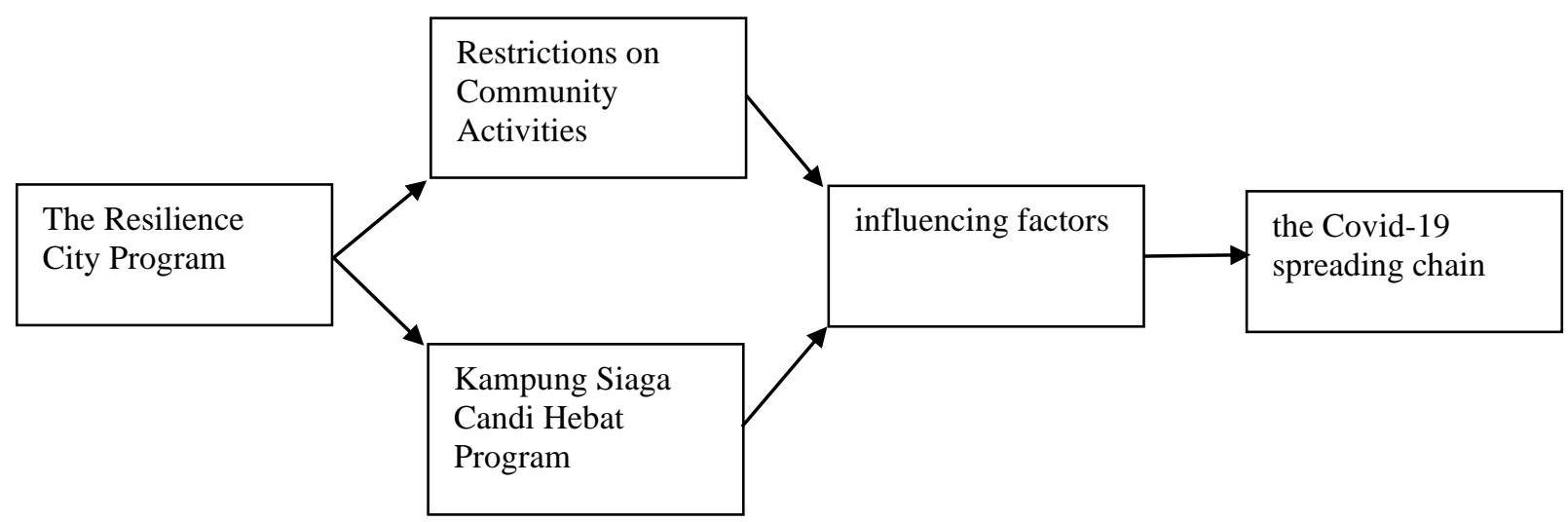

\section{Result and Discussion}

Unlike other cities that have implemented the Large-Scale Social Restrictions (Pembatasan Sosial Berskala Besar - PSBB), Semarang City, since the beginning of Covid-19, has chosen to restrict community activities (PKM). One of the basic considerations for the election is that PKM is more in line with President Jokowi's call to balance the health approach and the economic approach, which is termed a "brake and gas strategy." Restrictions are still applied to maintain public health's resilience but strive to keep economic activities running by using health protocols.

This concept was later implemented by the central government under the Restriction of Community Activities (PPKM) for the Java-Bali region for two weeks, 11-25 January 2021, no longer the PSBB. It is shown that the city of Semarang has chosen the right policy since the beginning of the pandemic, even though it initially received the spotlight because it was not by the PSBB policy selected by the central government at that time.

The legal basis for PPKM is the Instruction of the Minister of Home Affairs Number 1 of 2021 concerning Enforcement of Activity Limits to Control the Spread of Covid-19. The restrictions on community activities are laxer than the PSBB so that it still provides opportunities for businesspeople to 
carry out activities. The limitation is determined by the regional head, with zoning indicators, including the death rate above the national average mortality rate, the cure rate below the national average cure rate, the active case rate above the national active case rate average, and the housing occupancy rate. The sick or bed occupancy ratio for the intensive care unit (ICU) and isolation room is above 70 percent. Different from the total PSBB, PPKM still allows 25 percent of employees to work in offices. The new model of restrictions also allows group worship activities up to 50 percent of the capacity of places of worship.

The legal basis for the PSBB is the Regulation of the Minister of Health Number 1 of 2020 concerning Guidelines for Large-Scale Social Restrictions in the Acceleration of Handling Corona Virus Disease 2019 (Covid-19). Schools are prohibited from carrying out school activities, workplaces are closed (with a few exceptions), places of worship are also closed, residents are prohibited from carrying out socio-cultural activities that can crowd, public transportation is limited by the number of passengers and operating hours.

This description shows that the Semarang City Government is more experienced in implementing PKM than other city governments in Indonesia. Therefore, Semarang City should prevent and control the spread of Covid-19 through the Kampung Siaga Candi Hebat, but the results of these prevention and control efforts are not as expected. The number of Covid-19 cases is still high, even compared to the number of cases in several other cities.

From the author's notes, observations, interviews, and discussions in various forums, the core steps are taken in the program are to mobilize RT/RW as spearheads in the field. These steps are not optimal in reducing the number of Covid-19 cases due to several factors, namely:

a) Discipline factor: there are still many community members who are not disciplined and do not obey health protocols (wearing masks, washing hands, and maintaining social distance), driven by a lack of understanding of Covid-19 danger. Some residents do not even believe that Covid-19 exists.

b) Psychological factors: the heads of RT/RW feel uncomfortable when giving warnings to residents who do not obey, related to the culture of sungkan or ewuh pakewuh (in Javanese). As a result, the $\mathrm{RT} / \mathrm{RW}$ head prefers to remain silent when meeting residents who do not wear masks, do not wash their hands, or crowd around without maintaining their distance.

c) Oversight factor: the apparatus (Satpol PP, TNI, police) is felt to be less than optimal in supervising residents' activities, as evidenced in several public places (including markets, stalls, and sports facilities). There are still frequent crowds of people, among whom they do not wear masks.

These three factors indicate the need for a cultural approach in implementing resilience strategies, PKM, and the Kampung Siaga Candi Hebat. A persuasive approach based on local wisdom, which is by Eastern culture, will be more suitable than a repressive approach based on rules or laws. This model approach invites people to return to local wisdom values passed down from generation to generation, for example, cooperation, tolerance, and care for others.

A cultural approach needs to be applied to make citizens aware that discipline is necessary, not for oneself, but for maintaining others' safety. Likewise, they are psychologically mindful that if they do not follow the health protocol, they will feel embarrassed or ashamed. This approach will also raise awareness of 
the officials, the head of the RT/RW, that supervising and giving warnings is part of a noble mandate that must be carried out sincerely.

\section{Conclusion}

Based on the description above, normatively the City Resilience Program with the policy of Restricting Community Activities and the Kampung Siaga Candi Hebat is already perfect and precise. However, its implementation in the field still needs to be improved. The Kampung Siaga Candi Hebat has not been optimal, mainly due to the RT / RW's inadequate role in persuading residents to be disciplined and obedient to implementing health protocols.

Factors that influence the success of Covid-19 prevention within the framework of City Resilience, Restrictions on Community Activities, and Candi Hebat Alert Village are Discipline, psychological, and supervisory factors. These factors can be summarized into cultural factors, includes cultural weakness and local wisdom. That is why a cultural approach is essential in breaking the chain of spreading Covid-19. Discipline, psychology, and supervision are all factors that influence the success of the city's resilience strategy through the implementation of restrictions on community activities and Kampung Siaga Candi Hebat. That is why the implementation of a city resilience strategy must be based on the implementation of these factors through a cultural approach. If these steps are taken, the spread of Covid-19 will be limited. 


\section{References}

Desouza, K. C., \& Flanery, T. H. (2013). Designing, planning, and managing resilient cities: A conceptual framework. Cities, 35, 89-99. https://doi.org/10.1016/j.cities.2013.06.003

Johnson, C., \& Blackburn, S. (2014). Advocacy for urban resilience: UNISDR's Making Cities Resilient Campaign. Environment and Urbanization, 26(1), 29-52. https://doi.org/10.1177/0956247813518684

Maharani, S. I., Martanti, L. E., Bahiyatun, B., \& Nisa, R. (2018). Kajian Pemberdayaan Masyarakat Melalui Desa Siaga Dalam Rangka Upaya Penurunan Aki Di Bergas Kabupaten Semarang. Jurnal Kebidanan, 7(15), 10. https://doi.org/10.31983/jkb.v7i15.3244

Mehmood, A. (2016). Of resilient places: planning for urban resilience. European Planning Studies, 24(2), 407-419. https://doi.org/10.1080/09654313.2015.1082980

Paola, A. (2012). Making cities resilient: Increasing resilience to disasters at the local level.

Pemerintah Kota Semarang. (2016). Semarang Tangguh: Bergerak Bersama Menuju Semarang Tangguh (1st ed.).

Permadhi, P. L. O., \& Sudirga, I. M. (2020). Problematika Penerapan Pembatasan Kegiatan Masyarakat (Pkm) Kota Denpasar Berbasis Adat Dalam Upaya Penanganan Covid-19. Prosiding Webinar Nasional

Pujaningsih, N. N., \& Sucitawathi, I. G. A. A. D. (2020). Penerapan Kebijakan Pembatasan Kegiatan Masyarakat (Pkm) Dalam Penanggulangan Wabah Covid-19 Di Kota Denpasar. Moderat, 6(3), 458470.

Rahantoknam, L. D. (2013). Analisis Desa Siaga Di Desa Evu Kabupaten Maluku Tenggara. Mkmi, 1(1), 74-79.

Setiadi, R., \& Wulandari, F. (2016). Memadukan Strategi, Mewujudkan Ketahanan: Sebuah Pembelajaran Dari Pengembangan Strategi Ketahanan Kota Di Semarang. Jurnal Pengembangan Kota, 4(2), 95. https://doi.org/10.14710/jpk.4.2.95-105

Shafira, S., Kautsary, J., Widyasamratri, H., \& Rahman, B. (2020). Evaluasi Penerapan Kategori Dan Tujuan Kota Tangguh Pada Dokumen Kebijakan Strategi Ketahanan Kota 100 Resilient City. Pondasi, 25(2), 120. https://doi.org/10.30659/pondasi.v25i2.13039

Stumpp, E. M. (2013). New in town? On resilience and " Resilient Cities." Cities, 32, 164-166. https://doi.org/10.1016/j.cities.2013.01.003

Vale, L. J. (2014). The politics of resilient cities: Whose resilience and whose city? Building Research and Information, 42(2), 191-201. https://doi.org/10.1080/09613218.2014.850602

Peraturan Wali Kota Semarang Nomor 28 Tahun 2020, (2020). 